\title{
Rituximab efficiently depletes B cells in lung tumors and
}

\section{normal lung tissue [version 1; peer review: 2 approved]}

\author{
Albane Joly-Battaglini 1,2, Clara Hammarström³ ${ }^{3}$ Branislava Stankovic ${ }^{1,2}$, \\ Henrik Aamodt1,2,4, Johan Stjärne5, Odd Terje Brustugun', Åslaug Helland6,7, \\ Inger Øynebråten ${ }^{1,2}$, Alexandre Corthay ${ }^{1,2,8}$
}

\footnotetext{
${ }^{1}$ Tumor Immunology group, Department of Pathology, Oslo University Hospital, Oslo, Norway

${ }^{2}$ Centre for Immune Regulation, University of Oslo, Oslo, Norway

${ }^{3}$ Department of Pathology, Oslo University Hospital, Oslo, Norway

${ }^{4}$ Department of Cardiothoracic Surgery, Oslo University Hospital, Oslo, Norway

${ }^{5}$ Betanien Hospital, Skien, Norway

${ }^{6}$ Department of Oncology, Norwegian Radium Hospital, Oslo University Hospital, Oslo, Norway

${ }^{7}$ Department of Cancer Genetics, Institute for Cancer Research, Norwegian Radium Hospital, Oslo University Hospital, Oslo, Norway

${ }^{8}$ Department of Biosciences, University of Oslo, Oslo, Norway
}

\author{
V1 First published: 08 Jan 2016, 5:38 \\ https://doi.org/10.12688/f1000research.7599.1 \\ Latest published: 08 Jan 2016, 5:38 \\ https://doi.org/10.12688/f1000research.7599.1
}

\begin{abstract}
Rituximab is a monoclonal antibody that targets the CD20 B-cellspecific antigen and is widely used as therapy for B-cell lymphoma. Since rituximab depletes both malignant and normal $B$ cells, it is increasingly being used to treat various conditions in which normal $B$ cells have a pathogenic role, such as rheumatoid arthritis and multiple sclerosis. It is well-established that rituximab efficiently eliminates B cells in blood, lymph nodes, and spleen. In contrast, the effect of rituximab in non-lymphoid tissues remains poorly documented and is debated. Here, we report a rheumatoid arthritis patient who was treated with rituximab before receiving thoracic surgery for non-small cell lung cancer. Using flow cytometry and immunohistochemistry, we show that rituximab efficiently depleted CD20-positive B cells in a primary lung tumor, in lung-associated lymph nodes, and in normal lung tissue. We conclude that rituximab may be very efficient at depleting normal $B$ cells in the lungs. This property of rituximab may potentially be exploited for the treatment of conditions in which pathogenic $B$ cells reside in the lungs. On the other hand, the clearance of lung $B$ cells may provide an explanation for the rare cases of severe non-infectious pulmonary toxicity of rituximab.
\end{abstract}

\section{Keywords}

rituximab, B cells, depletion, monoclonal antibody, lungs, tumor , lymph node, non-small cell lung cancer

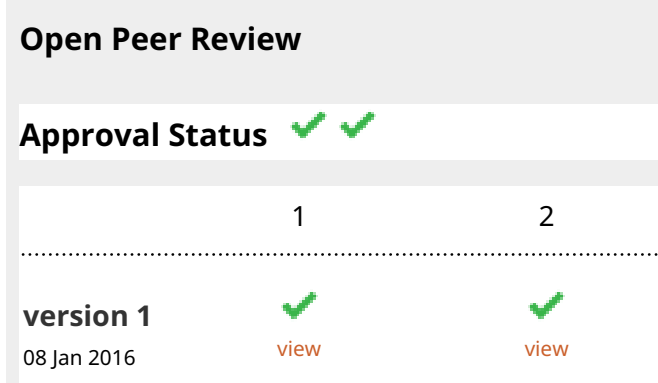

1. Bertrand Huard, Joseph Fourier University, Grenoble, France

2. Hilde Schjerven, University of California, San Francisco, San Francisco, USA

Etapong Fonabei Ayongaba, University of California, San Francisco, San Francisco, USA University of Oslo, Oslo, Norway

Any reports and responses or comments on the article can be found at the end of the article. 
Corresponding author: Alexandre Corthay (alexandre.corthay@ibv.uio.no)

Competing interests: The authors declare that they have no competing interests.

Grant information: This work was supported by grants from the Research Council of Norway, Norway Grants 2009-2014 under project contract NFI/R/2014/051 (to A. Corthay), and the Norwegian Cancer Society.

The funders had no role in study design, data collection and analysis, decision to publish, or preparation of the manuscript.

Copyright: ( $) 2016$ Joly-Battaglini A et al. This is an open access article distributed under the terms of the Creative Commons Attribution License, which permits unrestricted use, distribution, and reproduction in any medium, provided the original work is properly cited.

How to cite this article: Joly-Battaglini A, Hammarström C, Stankovic B et al. Rituximab efficiently depletes B cells in lung tumors and normal lung tissue [version 1; peer review: 2 approved] F1000Research 2016, 5:38

https://doi.org/10.12688/f1000research.7599.1

First published: 08 Jan 2016, 5:38 https://doi.org/10.12688/f1000research.7599.1 


\section{Introduction}

Rituximab was the first monoclonal antibody to be approved for the treatment of cancer and it is estimated that $>4$ million people have been treated with rituximab worldwide ${ }^{1}$. Rituximab is a depleting chimeric anti-CD20 monoclonal antibody routinely used for the treatment of B-cell lymphoma ${ }^{2-4}$. The B cell-specific antigen CD20 is expressed on all normal B cells, except for early B cell precursors and antibody-secreting plasma cells, and by nearly all B-cell lymphomas. Since rituximab depletes both malignant and normal $\mathrm{B}$ cells, its use has been extended to non-cancerous conditions in which normal B cells are believed to play a central role in pathogenesis. Significant clinical benefits have been reported for the treatment of autoimmune diseases, such as rheumatoid arthritis, multiple sclerosis, vasculitis, Sjögren's syndrome, and scleroderma ${ }^{5-9}$. The mechanism whereby rituximab depletes B cells is not fully understood but there is evidence for complement-dependent cell lysis and for antibody-dependent cellular cytotoxicity ${ }^{2,10,11}$. It has been shown that rituximab efficiently eliminates normal and malignant B cells in blood and in lymphoid organs such as lymph nodes, spleen, and bone marrow ${ }^{12-14}$. In contrast, the effect in non-lymphoid tissues remains poorly documented. Here, we report the effect of rituximab in the lungs of a patient who was treated with rituximab because of rheumatoid arthritis before receiving thoracic surgery for non-small cell lung cancer.

\section{Methods}

\section{Ethics approval}

The Regional Committee for Medical and Health Research Ethics (Oslo, Norway) has approved the study (permit number: REK S-05307). Written informed consent for publication of the clinical details was obtained from all patients included in the study.

\section{Flow cytometry}

Patient blood was sampled from a central venous catheter before the start of surgery and collected into ethylenediaminetetraacetic acid (EDTA)-containing tubes. Peripheral blood mononuclear cells (PBMCs) were isolated using a gradient (Lymphoprep, Axis-Shield, Oslo, Norway; cat. no. 1114544). Fresh biopsies from the tumor, a lung-associated lymph node, and normal lung tissue, were sampled under sterile conditions in the operating room, after the removal of the lung lobe by the surgeon. Samples were treated enzymatically with $2 \mathrm{mg} / \mathrm{ml}$ collagenase A and 50 units/ml DNase (both from Roche, Basel, Switzerland; collagenase A, cat. no. 10103586001; DNase, cat. no. 11284932001) and incubated for $1 \mathrm{~h}$ on a magnet stirrer at $37^{\circ} \mathrm{C}$. Single-cell suspension was obtained by squeezing the dissolved tissue through a $100 \mu \mathrm{m}$ mesh and centrifuging at $300 \mathrm{~g}$ for $7 \mathrm{~min}$. Nonspecific binding was blocked by incubation with $12.5 \mu \mathrm{g} / \mathrm{ml} \mathrm{IgG}$ purified from pooled mouse sera (Sigma-Aldrich, St. Louis, Missouri, USA; cat. no. I8765). Cells were stained in a 96-well plate for $20 \mathrm{~min}$ on ice with fluorochrome-labeled monoclonal antibodies diluted 1:10 in phosphate-buffered saline (SigmaAldrich, cat. no. D8537) supplemented with $10 \%$ foetal bovine serum (Sigma-Aldrich cat. no. F7524). The following monoclonal antibodies were used (all from BioLegend, San Diego, California, USA): anti-CD3 (clone UCHT1, cat. no. 300415); anti-CD4 (clone OKT4, cat. no. 317409); anti-CD8 (clone SK1, cat. no. 344713); anti-CD14 (clone HCD14, cat. no. 325617); anti-CD19 (clone HIB19, cat. no. 302227); anti-CD45 (clone HI30, cat. no. 304029);
anti-HLA-DR (clone L243, cat. no. 307610). Stained cells were analyzed with a BD LSRFortessa ${ }^{\mathrm{TM}}$ Cell Analyzer instrument (BD Biosciences, Franklin Lakes, New Jersey, USA, model no. 647794E6) and FlowJo software version 10 (FlowJo, Ashland, Oregon, USA).

\section{Tissue preparation and immunohistochemistry}

For light microscopy, $4 \mu \mathrm{m}$ thick sections from formalin-fixed paraffin-embedded tissue were automatically stained with hematoxylin and eosin in a Sakura Tissue-Tek Prisma instrument (Sakura Finetek, Torrance, California, USA). The immunostainings were done on a Dako Autostainer instrument (Dako, Agilent Technologies, Santa Clara, California, USA, model Link 48), and the incubation time for the primary antibodies was $20 \mathrm{~min}$. CD3 was immunostained by clone SP7 (a monoclonal rabbit antibody, diluted 1:150; Thermo Scientific, Waltham, Massachusetts, USA; cat. no. RM-9107), and CD20 was immunostained by clone L26 (a mouse IgG2a antibody, diluted 1:600; Dako, cat. no. M0755). The secondary detection was performed with Dako EnVision ${ }^{\mathrm{TM}}$ Flex (Dako, cat. no. K8000) for $20 \mathrm{~min}$, followed by diaminobenzidine (DAB) staining for $10 \mathrm{~min}$. The slides were thereafter treated with $\mathrm{CuSO} 4$ for 5 min before contrastaining with hematoxylin. Samples were examined with a Nikon Eclipse model $\mathrm{N} i$-U microscope (Nikon, Tokyo, Japan) equipped with Nikon Plan-Fluor objective lenses $(2 \times, 20 \times$, and $40 \times$ ) and images were taken with an Infinity 2 digital camera (Lumenera Corporation, Nepean, Ontario, Canada).

\section{Results}

A 62-year-old woman with seronegative rheumatoid arthritis was diagnosed in 2015 with lung adenocarcinoma, stage IIB (pT3N0Mx, TNM $7^{\text {th }}$ edition). The patient, a former heavy-smoker with a smoking history of 30 pack-years, underwent right lower lobectomy. The patient had been treated with Prednisolone (usually $5 \mathrm{mg}$ daily since 2005), as well as several different drugs (Methotrexate $10 \mathrm{mg} /$ week for 3 weeks in 2005 , Metoject $1 \times 10 \mathrm{mg}$ in 2005 and $2 \times 10 \mathrm{mg}$ in 2007, Plaquenil $400 \mathrm{mg}$ /day in January-February 2006, Arava $10 \mathrm{mg}$ /day for 8 days in 2006, and Enbrel $50 \mathrm{mg} /$ week from January 2008 to April 2009), all discontinued due to side-effects or inefficiency. Over the past six years before lung cancer diagnosis (2009-2014), the patient received seven cycles of rituximab (MabThera, 6 cycles of $2 \times 1000 \mathrm{mg}$ and 1 cycle of $2 \times 500 \mathrm{mg}$ ) with only moderate clinical effect. Serum immunoglobulin (Ig) levels were normal before initiation of the rituximab treatment $(\operatorname{IgG}=6.1 \mathrm{~g} / \mathrm{L}$; $\operatorname{IgA}=1.3 \mathrm{~g} / \mathrm{L} ; \operatorname{IgM}=2.1 \mathrm{~g} / \mathrm{L}$ ), excluding any B-cell immunodeficiency. Serum $\operatorname{IgA}$ and $\operatorname{IgM}$ levels remained normal $(\operatorname{IgA} \geq 0.9 \mathrm{~g} / \mathrm{L}$; $\operatorname{IgM} \geq 1.2 \mathrm{~g} / \mathrm{L}$ ), whereas low IgG levels (4.2-5.6g/L) were observed several times over the past three years. The last rituximab cycle $(2 \times 1000 \mathrm{mg})$ was given 6 months pre-operatively.

Upon informed consent, the patient was included in a research project. A pre-operative blood sample and biopsy samples from the tumor, a lung-associated lymph node, and normal lung were collected for flow cytometric analysis. For comparison, samples from a control patient with lung adenocarcinoma (not treated with rituximab) were analyzed. The control patient had $\mathrm{CD} 19^{+} \mathrm{B}$ cells in blood and tumor (Figure 1A,B). In the rituximab-treated patient, CD $19^{+} \mathrm{B}$ cells were virtually absent from the blood (Figure 1C) and strongly reduced in the tumor $(0.2 \%$ of all CD45-positive 


\section{Control patient}

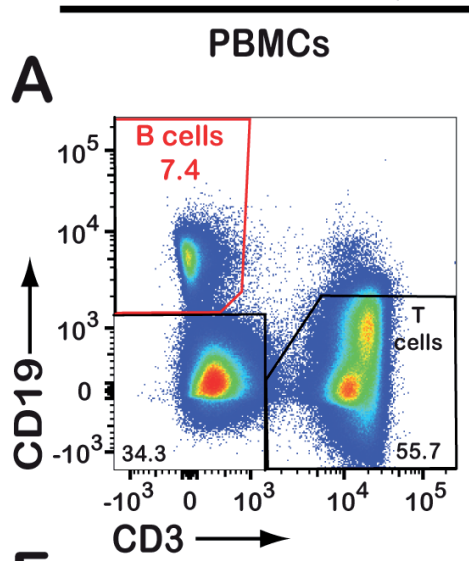

E

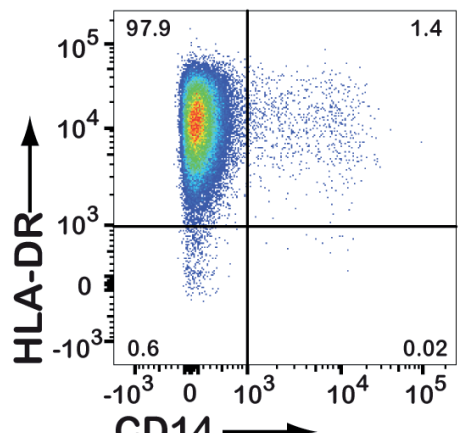

1

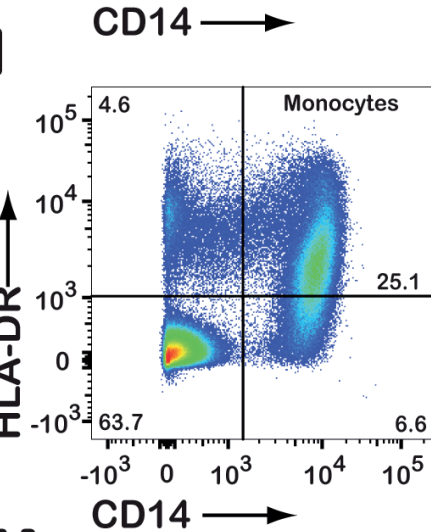

M

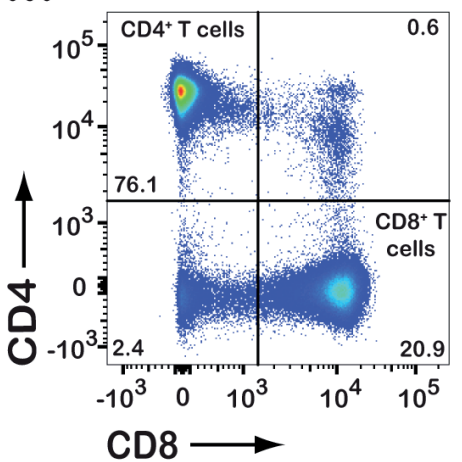

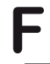
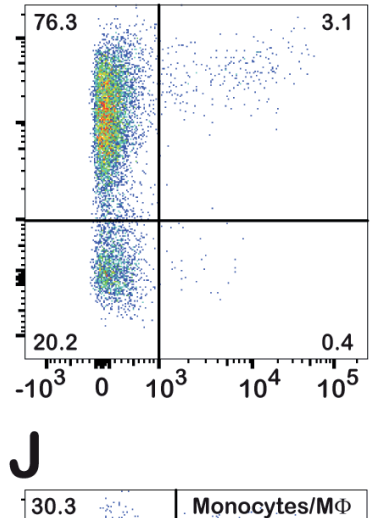

Tumor
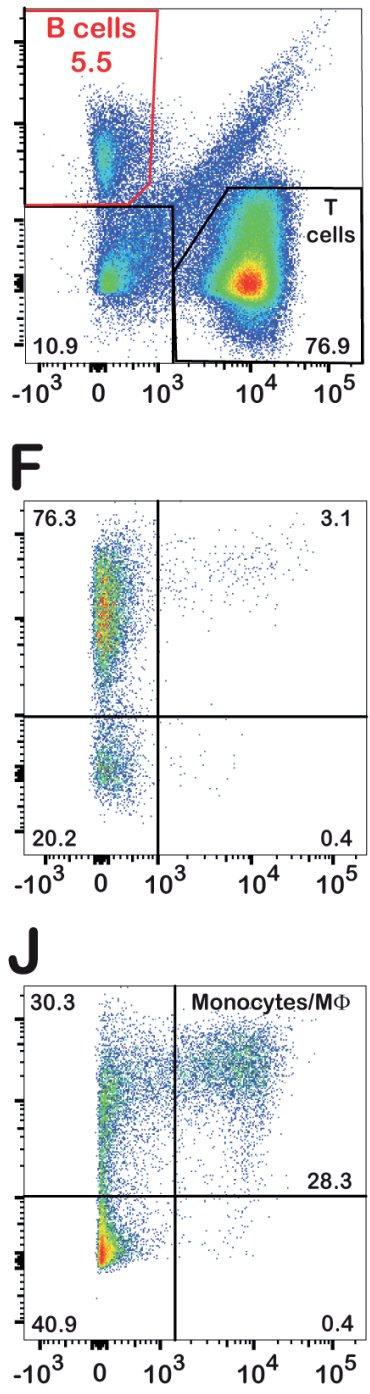

$\mathrm{N}$

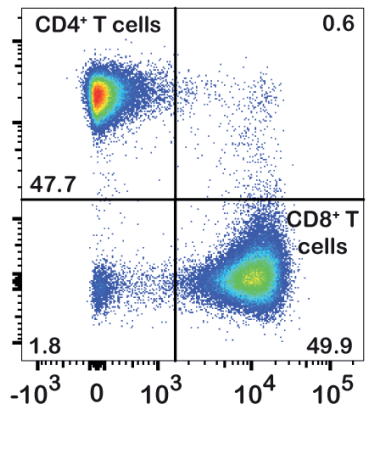

Rituximab-treated patient

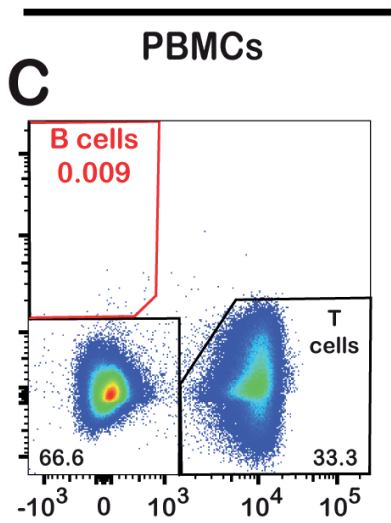

Tumor

D

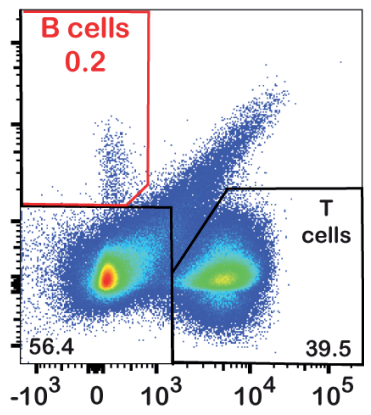

G

$\mathrm{H}$
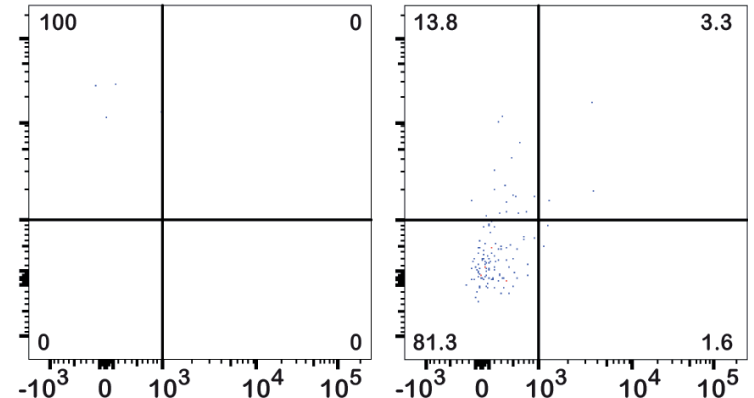

$\mathrm{K}$
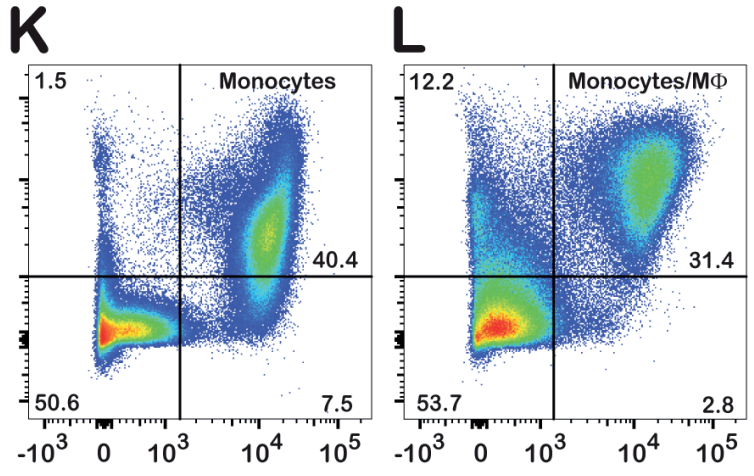

O

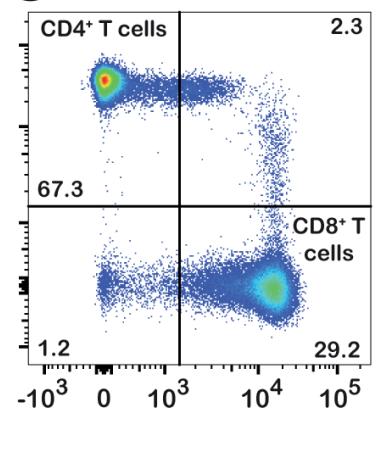

$\mathbf{P}$

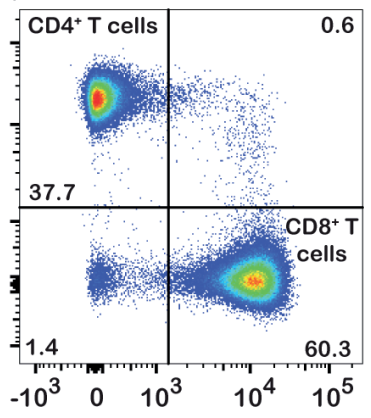

Figure 1. Flow cytometric analysis reveals the absence of tumor-infiltrating CD19+ B cells in a patient treated with rituximab. Upon chest surgery for removal of a lung tumor from a patient previously treated with rituximab, tumor biopsy and serum samples were analyzed by flow cytometry. Results from a control lung cancer patient (not treated with rituximab) are shown for comparison. Both patients were diagnosed with lung adenocarcinoma. CD45-positive leukocytes were gated and analyzed further for expression of CD19/CD3 (A-D), HLADR/CD14 (E-L), and CD4/CD8 (M-P). The dot plots $\mathbf{E}-\mathbf{H}$ show expression of HLA-DR and CD14 by CD19-positive B cells only (red gates in A-D). Numbers in quadrants indicate the percentage of cells detected. PBMCs, peripheral blood mononuclear cells. 
leukocytes, Figure 1D). The remaining $\mathrm{CD} 19^{+} \mathrm{B}$ cells in the tumor were mostly HLA-DR-negative (Figure $1 \mathrm{H}$ ) indicating that they were plasma cells which typically lack the CD20 antigen. Rituximab did not deplete other types of immune cells, such as monocytes/ macrophages, $\mathrm{CD}^{+} \mathrm{T}$ cells, or $\mathrm{CD}^{+} \mathrm{T}$ cells (Figure $1 \mathrm{I}-\mathrm{P}$ ). Flow cytometric analysis of a lung-associated lymph node and normal lung tissue revealed virtual absence of $\mathrm{CD} 19^{+} \mathrm{B}$ cells in the rituximab-treated patient (Figure 2).

Immunohistochemistry of formalin-fixed paraffin-embedded routine specimen was performed by staining for CD3 and CD20. In the control patient, the inflammatory infiltrate in and around the tumor contained both $\mathrm{CD} 20^{+} \mathrm{B}$ cells (Figure $3 \mathrm{~A}, \mathrm{C}$ ) and $\mathrm{CD}^{+}$ $\mathrm{T}$ cells (Figure $3 \mathrm{E}, \mathrm{G}$ ). In contrast, the inflammatory infiltrate in the rituximab-treated patient contained $\mathrm{T}$ cells (Figure 3F,H) but virtually no B cells (Figure 3B,D), in accordance with the flow cytometry data.
The same pattern was observed in normal lung and in lungassociated lymph nodes. In the control patient, normal lung tissue contained peribronchial lymphoid foci with both $\mathrm{CD} 20^{+}$ B cells (Figure 4A) and CD3 ${ }^{+} \mathrm{T}$ cells (Figure 4C). In contrast, the peribronchial lymphoid foci from the rituximab-treated patient contained T cells (Figure 4D) but virtually no B cells (Figure 4B). In control lung-associated lymph nodes, a normal lymphocyte distribution was observed with typical germinal centers with a high density of $\mathrm{CD} 20^{+} \mathrm{B}$ cells (Figure $5 \mathrm{~A}$ ), whereas $\mathrm{CD}^{+} \mathrm{T}$ cells were mostly present outside the germinal centers (Figure 5C). In sharp contrast, lung-associated lymph nodes from the rituximab-treated patient contained virtually no B cells (Figure 5B) and were homogenously and densely populated by $\mathrm{T}$ cells (Figure 5D). The black dots in Figure 5B represent anthracotic pigment in macrophages. Thus, rituximab therapy resulted in efficient depletion of CD20positive B cells throughout the lungs, including in a lung tumor, in normal lung tissue, and in lung-associated lymph nodes.
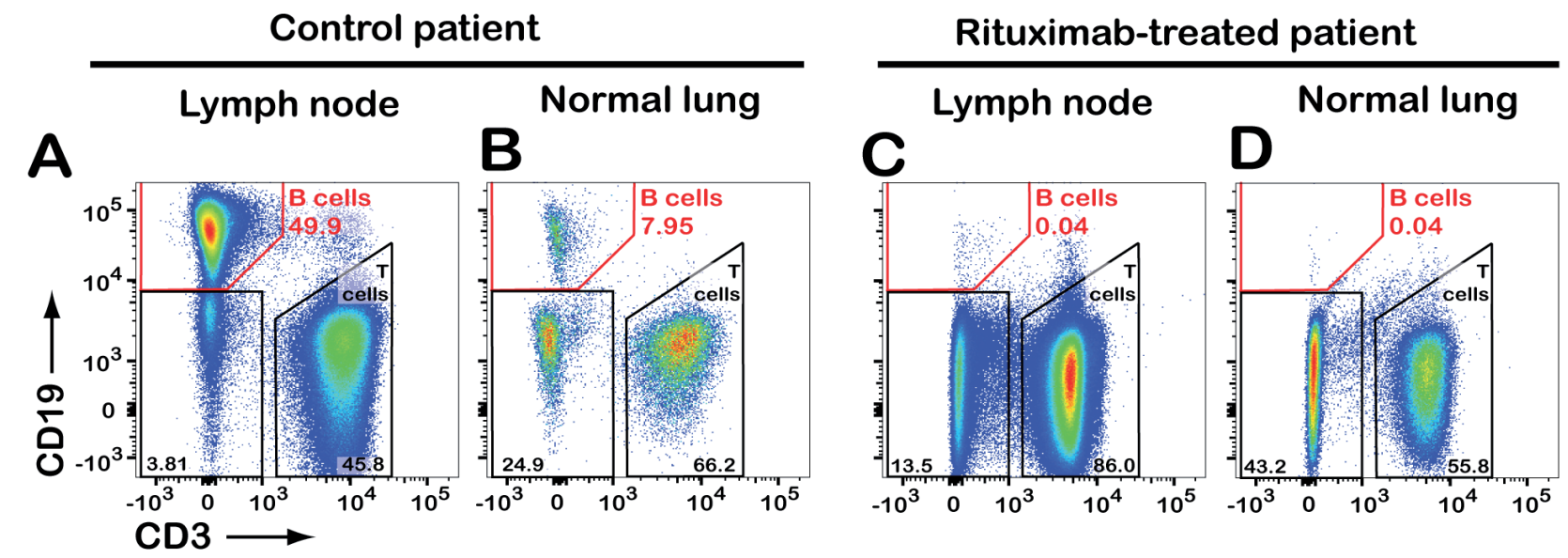

Figure 2. Rituximab depletes B cells in lung-associated lymph node and normal lung tissue. Upon chest surgery for removal of tumorcontaining lung lobe from a patient previously treated with rituximab, a lung-associated lymph node and normal lung tissue samples were analyzed by flow cytometry. Results from a control lung cancer patient (not treated with rituximab) are shown for comparison. Both patients were diagnosed with lung adenocarcinoma. Live leukocytes (CD45-positive, propidium iodide-negative) were gated and analyzed further for expression of CD19 (B cells) and CD3 (T cells). Numbers indicate the percentage of cells detected in each gate. 
Control patient
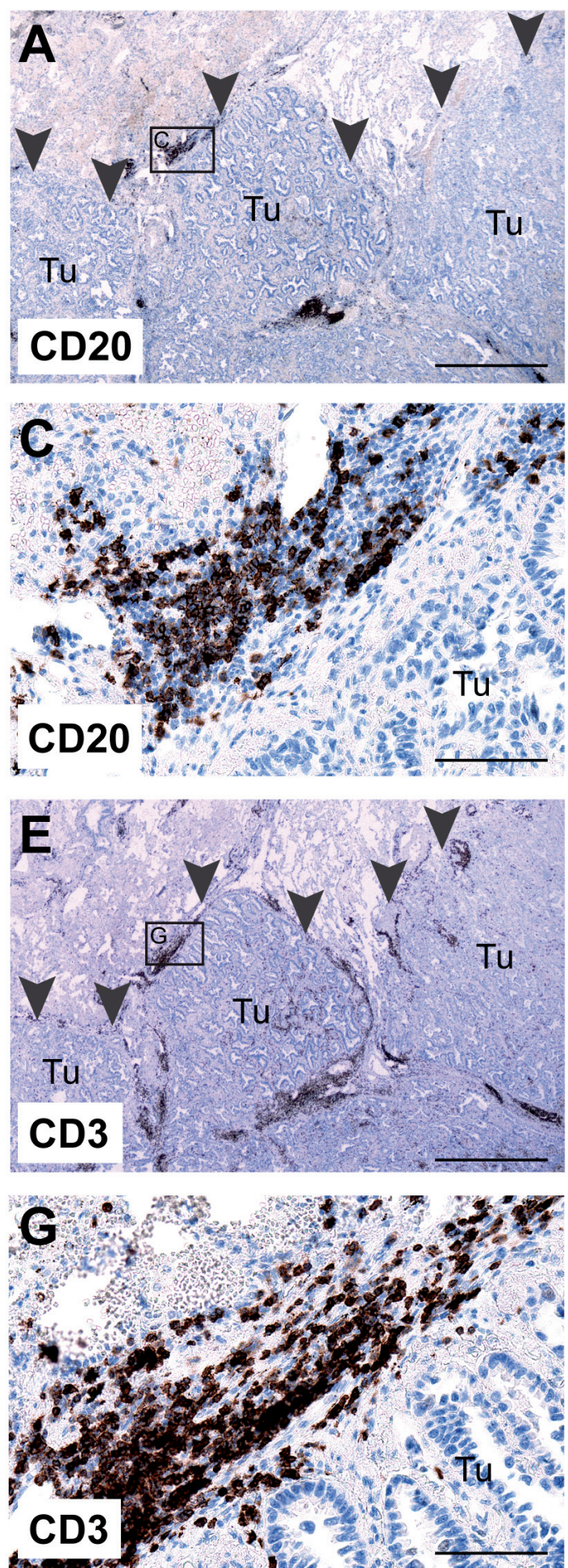

Rituximab-treated patient
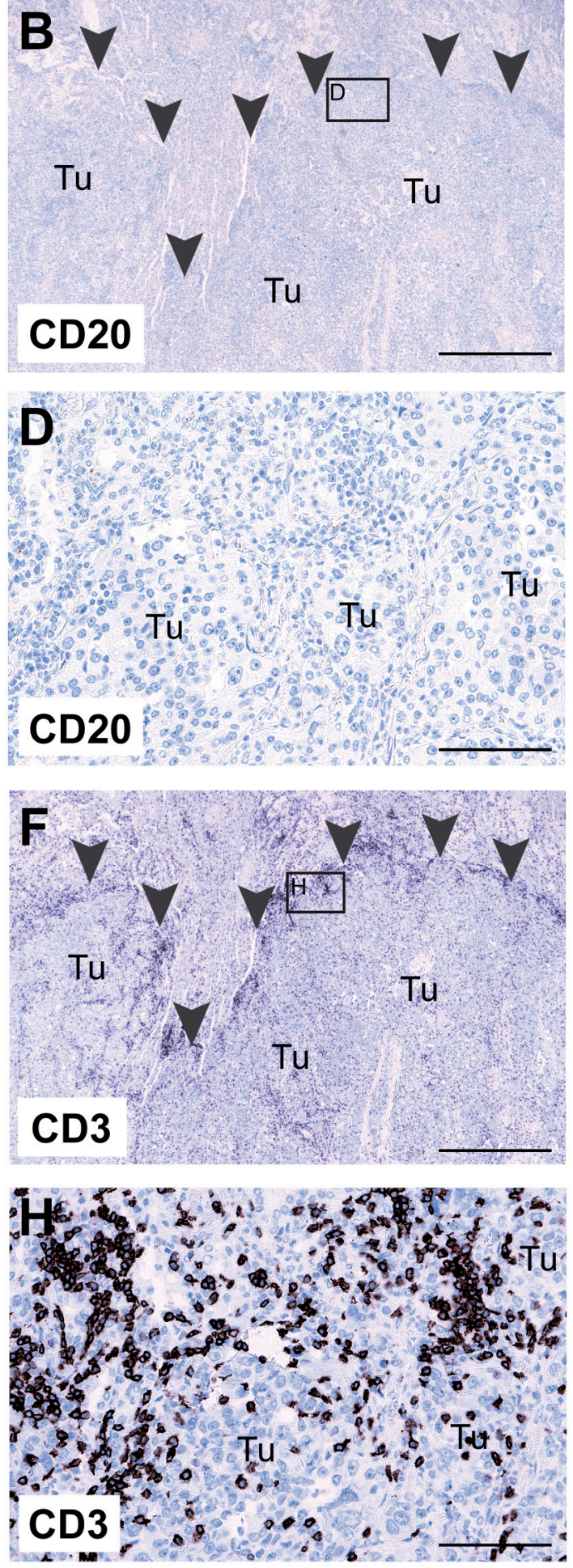

Figure 3. Absence of $\mathrm{CD}^{2} \mathrm{O}^{+} \mathrm{B}$ cells in primary lung tumor from a patient treated with rituximab. Lung tissue sections from a control patient (left) and from a rituximab-treated patient (right) were stained with anti-CD20 (A-D) or anti-CD3 (E-H) antibodies, and contrastained with hematoxylin. Both patients were diagnosed with lung adenocarcinoma. Arrowheads delineate the border of the tumor. Small boxes in $\mathbf{A}, \mathbf{B}, \mathbf{E}$, and $\mathbf{F}$ indicate magnified areas in $\mathbf{C}, \mathbf{D}, \mathbf{G}$, and $\mathbf{H}$, respectively. Tu, tumor tissue. $\mathbf{A}, \mathbf{B}, \mathbf{E}$, and $\mathbf{F}$ : $20 \times$ magnification; scalebar $=1 \mathrm{~mm}$. $\mathbf{C}, \mathbf{D}, \mathbf{G}$, and $\mathbf{H}$ : 200x magnification; scalebar $=100 \mu \mathrm{m}$. 


\section{Control patient}
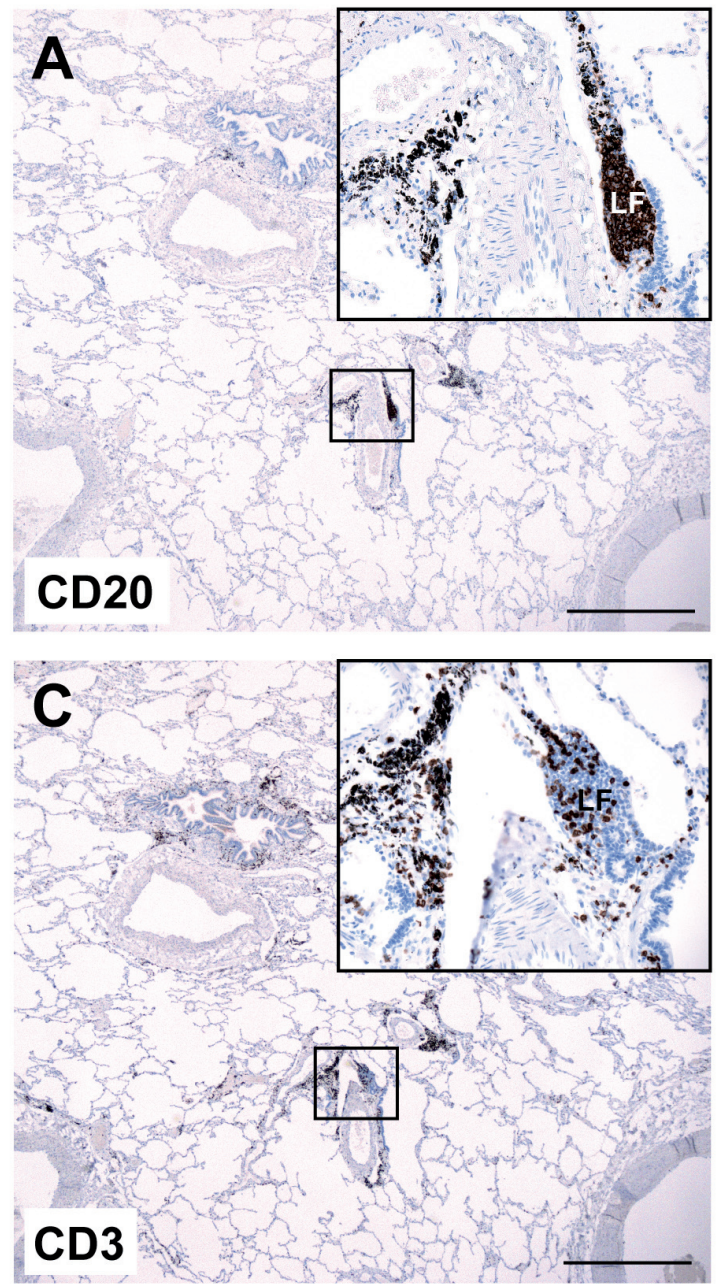

\section{Rituximab-treated patient}
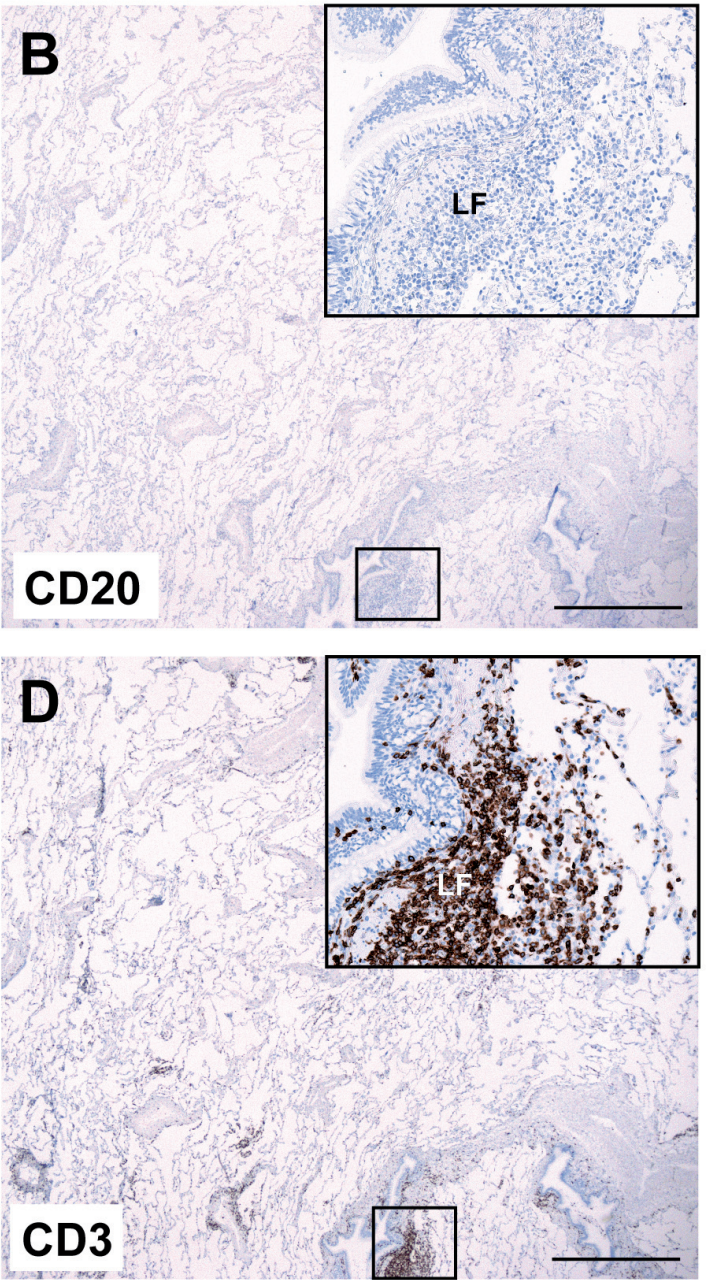

Figure 4. Absence of $\mathrm{CD}^{2} \mathrm{O}^{+} \mathrm{B}$ cells in normal lung tissue from a patient treated with rituximab. Normal lung tissue sections from a control patient (left) and from a rituximab-treated patient (right) were stained with anti-CD20 (A,B) or anti-CD3 (C,D) antibodies, and contrastained with hematoxylin. Both patients were diagnosed with lung adenocarcinoma. Small boxes indicate areas that are magnified in the upper right inserts. LF, peribronchial lymphoid focus. Main images: $20 \times$ magnification; scalebar $=1 \mathrm{~mm}$. Upper right inserts: $200 \times$ magnification. 


\section{Control patient}
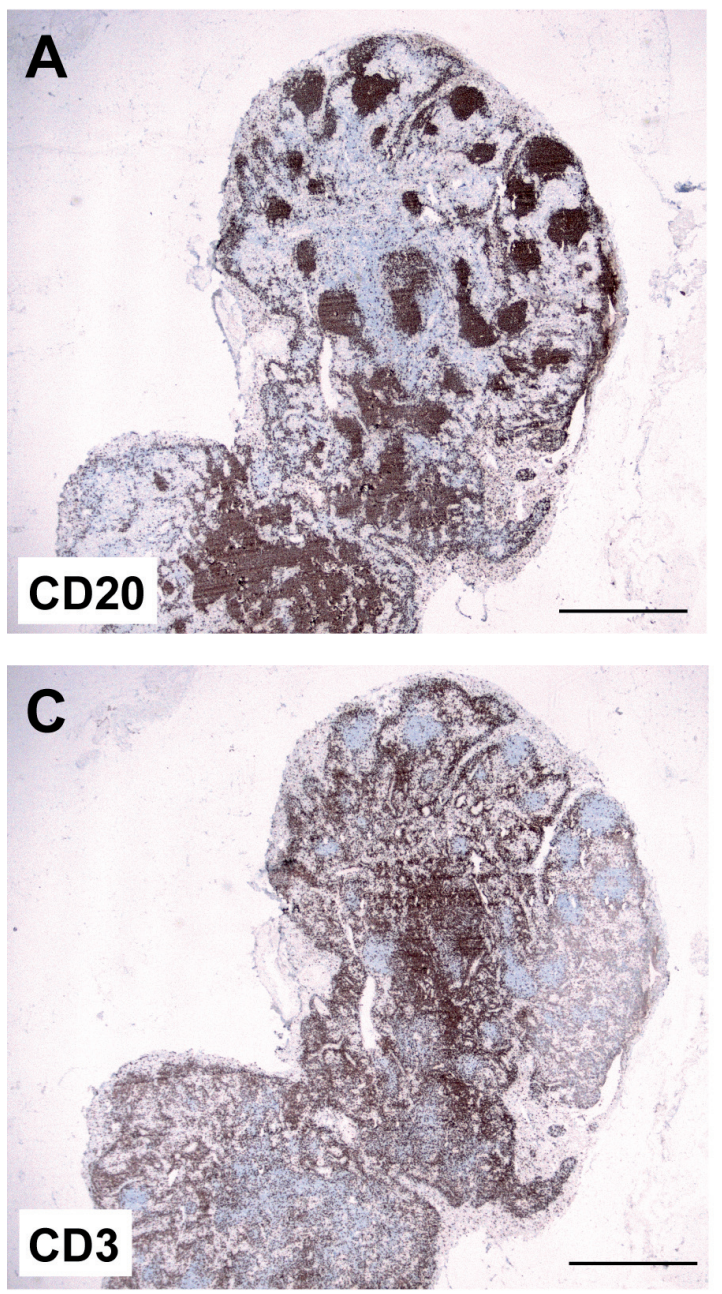

\section{Rituximab-treated patient}
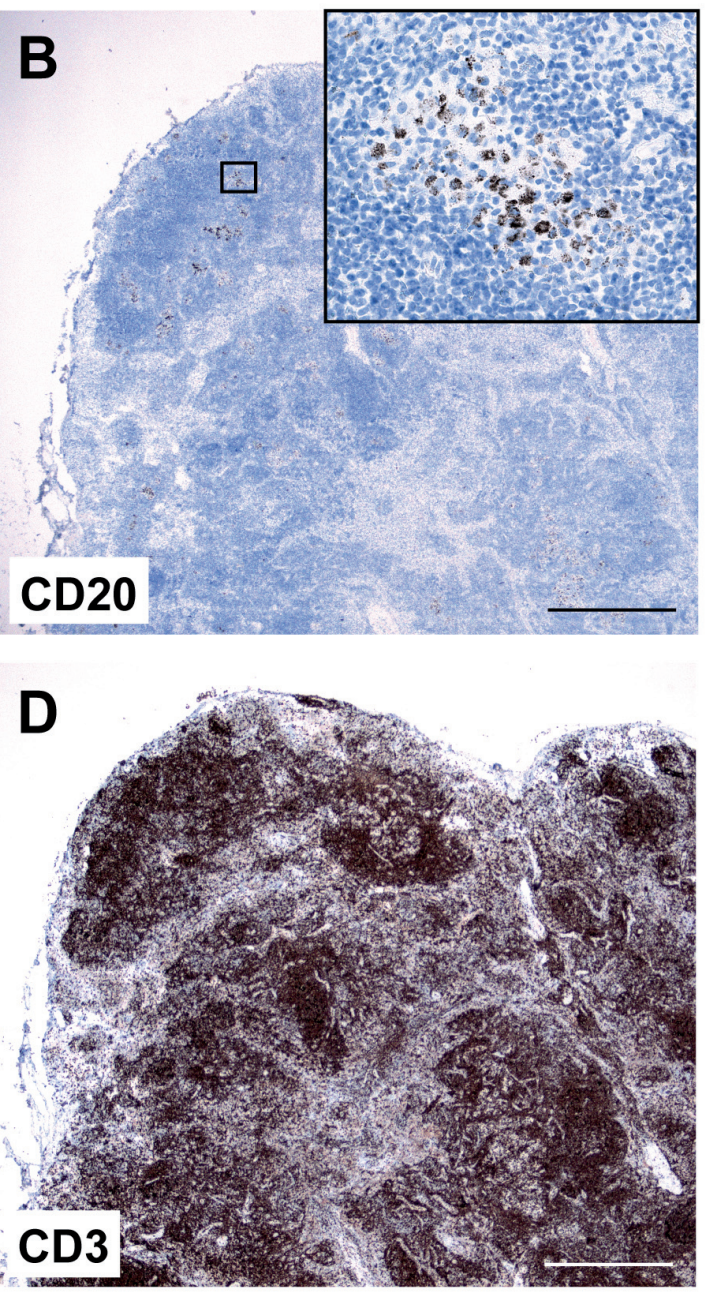

Figure 5. Absence of $\mathrm{CD}^{2} \mathrm{O}^{+} \mathrm{B}$ cells in lung-associated lymph node from a patient treated with rituximab. A lung-associated lymph node from a control patient (left) and from a rituximab-treated patient (right) were stained with anti-CD20 (A-B) or anti-CD3 (C-D) antibodies, and contrastained with hematoxylin. Both patients were diagnosed with lung adenocarcinoma. The small box in $\mathbf{B}$ indicates the area that is magnified in the upper right insert. The black dots in $\mathbf{B}$ represent anthracotic pigment in macrophages. Main images: 20x magnification; scalebar $=1 \mathrm{~mm}$. Upper right insert in B: 400x magnification.

\section{Discussion}

Rituximab was initially developed with the goal of eradicating B-lymphoma cells which typically reside in blood and lymphoid organs ${ }^{1-4}$. It is now well established that rituximab efficiently eliminates normal and malignant $\mathrm{B}$ cells in those anatomical locations ${ }^{12-14}$. In contrast, current knowledge on the effect of rituximab therapy in non-lymphoid tissues remains fragmentary. This is problematic because rituximab is being considered as a therapeutic option for a number of non-malignant conditions such as autoimmune diseases ${ }^{5-9}$ and myalgic encephalopathy/chronic fatigue syndrome ${ }^{15}$. In autoimmune diseases, depletion of pathogenic B cells in inflamed tissues is likely to be required to obtain clinical benefits. In the cerebrospinal fluid of patients with multiple sclerosis, rituximab therapy was shown to result in $90-95 \%$ depletion of B cells ${ }^{16,17}$. In the salivary glands of patients with Sjögren's syndrome, the efficiency of rituximab remains controversial because both complete and partial depletion of B cells have been reported ${ }^{8,18}$. Similarly, the effect of rituximab on synovial B cells is debated since various levels of depletion have been reported in patients with rheumatoid arthritis ${ }^{12,19,20}$.

Our case report illustrates that rituximab may efficiently deplete $\mathrm{B}$ cells in the lungs, including lung tumor, normal lung tissue, and 
lung-associated lymph nodes. This property of rituximab is of particular interest for the treatment of conditions in which pathogenic $\mathrm{B}$ cells reside in the lungs, such as antisynthetase syndrome, granulomatosis with polyangiitis, and scleroderma-associated interstitial lung disease ${ }^{9,21,22}$. On the other hand, the strong B cell-depleting effect in the lungs may provide an explanation for the rare cases of severe non-infectious pulmonary toxicity of rituximab ${ }^{23,24}$. Rituximabassociated lung disease is a rare but potentially fatal complication of rituximab therapy, whose pathogenic mechanism remains to be elucidated ${ }^{23}$.

Rituximab therapy was associated with virtual absence of tumorinfiltrating $B$ cells in a patient with lung adenocarcinoma. Nonsmall cell lung cancer (NSCLC) tumors typically contain tertiary lymphoid structures with a high frequency of $\mathrm{CD} 20^{+}$follicular $\mathrm{B}$ cells ${ }^{25}$. Tumor-infiltrating immune cells, including B cells, may represent an ongoing protective immune response against the malignant cells ${ }^{26,27}$. In fact, it has recently been reported that a high density of follicular B cells correlated with longer patient survival in $\mathrm{NSCLC}^{25}$. Therefore, rituximab-mediated depletion of tumor-infiltrating normal B cells may potentially have a detrimental impact on the antitumor immune response, particularly in NSCLC.

\section{Author contributions}

HA, OTB, IØ, and AC conceived the study. AC supervised the study. JS and $\AA \mathrm{H}$ managed the patient. AJB, CH, BS, JS, and $\AA \mathrm{H}$ acquired the data. AJB, $\mathrm{CH}, \mathrm{BS}$, JS, and AC analyzed the data and prepared the figures. AC prepared the first draft of the manuscript. All authors were involved in the revision of the draft manuscript and have agreed to the final content.

\section{Competing interests}

The authors declare that they have no competing interests.

\section{Grant information}

This work was supported by grants from the Research Council of Norway, Norway Grants 2009-2014 under project contract NFI/ R/2014/051 (to A. Corthay), and the Norwegian Cancer Society.

The funders had no role in study design, data collection and analysis, decision to publish, or preparation of the manuscript.

\section{Acknowledgements}

We thank Ingjerd Solvoll, Inger Johanne Ryen, and Kahsai Beraki for technical help.
1. Lim SH, Levy R: Translational medicine in action: anti-CD20 therapy in lymphoma. $J$ Immunol. 2014; 193(4): 1519-1524.

PubMed Abstract | Publisher Full Text

2. Reff ME, Carner $\mathrm{K}$, Chambers $\mathrm{KS}$, et al.: Depletion of $\mathrm{B}$ cells in vivo by a chimeric mouse human monoclonal antibody to CD20. Blood. 1994; 83(2): 435-445. PubMed Abstract

3. Maloney DG, Liles TM, Czerwinski DK, et al:: Phase I clinical trial using escalating single-dose infusion of chimeric anti-CD20 monoclonal antibody (IDEC-C2B8) in patients with recurrent B-cell lymphoma. Blood. 1994; 84(8): 2457-2466. PubMed Abstract

4. Maloney DG, Grillo-López AJ, White CA, et al:: IDEC-C2B8 (Rituximab) anti-CD20 monoclonal antibody therapy in patients with relapsed low-grade non-Hodgkin's lymphoma. Blood. 1997; 90(6): 2188-2195. PubMed Abstract

5. Edwards JC, Szczepanski L, Szechinski J, et al.: Efficacy of B-cell-targeted therapy with rituximab in patients with rheumatoid arthritis. N Engl J Med. 2004; 350(25): 2572-2581.

PubMed Abstract | Publisher Full Text

6. Hauser SL, Waubant E, Arnold DL, et al: B-cell depletion with rituximab in relapsing-remitting multiple sclerosis. N Engl J Med. 2008; 358(7): 676-688. PubMed Abstract | Publisher Full Text

7. Stone JH, Merkel PA, Spiera R, et al:: Rituximab versus cyclophosphamide for ANCA-associated vasculitis. N Engl J Med. 2010; 363(3): 221-232. PubMed Abstract | Publisher Full Text | Free Full Text

8. Pijpe J, Meijer JM, Bootsma $\mathrm{H}$, et al:: Clinical and histologic evidence of salivary gland restoration supports the efficacy of rituximab treatment in Sjögren's syndrome. Arthritis Rheum. 2009; 60(11): 3251-3256. PubMed Abstract | Publisher Full Text

9. Daoussis D, Liossis SN, Tsamandas AC, et al.: Experience with rituximab in scleroderma: results from a 1-year, proof-of-principle study. Rheumatology (Oxford). 2010; 49(2): 271-280.

PubMed Abstract | Publisher Full Text | Free Full Text

10. Weng WK, Levy R: Two immunoglobulin $\mathrm{G}$ fragment $\mathrm{C}$ receptor polymorphisms independently predict response to rituximab in patients with follicular lymphoma. J Clin Oncol. 2003; 21(21): 3940-3947.

PubMed Abstract | Publisher Full Text

11. Anolik JH, Campbell D, Felgar RE, et al.: The relationship of FcgammaRIlla genotype to degree of B cell depletion by rituximab in the treatment of systemic lupus erythematosus. Arthritis Rheum. 2003; 48(2): 455-459. PubMed Abstract | Publisher Full Text

12. Teng YK, Levarht EW, Hashemi M, et al.: Immunohistochemical analysis as a means to predict responsiveness to rituximab treatment. Arthritis Rheum. 2007; 56(12): 3909-3918.

PubMed Abstract | Publisher Full Text

13. Cioc AM, Vanderwerf SM, Peterson BA, et al.: Rituximab-induced changes in hematolymphoid tissues found at autopsy. Am J Clin Pathol. 2008; 130(4): 604-612. PubMed Abstract | Publisher Full Text

14. Audia S, Samson M, Guy J, et al:: Immunologic effects of rituximab on the human spleen in immune thrombocytopenia. Blood. 2011; 118(16): 4394-4400. PubMed Abstract | Publisher Full Text | Free Full Text

15. Fluge $\varnothing$, Risa K, Lunde S, et al.: B-Lymphocyte Depletion in Myalgic Encephalopathy/Chronic Fatigue Syndrome. An Open-Label Phase II Study with Rituximab Maintenance Treatment. PLoS One. 2015; 10(7): e0129898. PubMed Abstract | Publisher Full Text | Free Full Text

16. Cross $\mathrm{AH}$, Stark JL, Lauber J, et al:: Rituximab reduces $\mathbf{B}$ cells and T cells in cerebrospinal fluid of multiple sclerosis patients. J Neuroimmunol. 2006; 180(1-2): 63-70.

PubMed Abstract | Publisher Full Text | Free Full Text

17. Piccio L, Naismith RT, Trinkaus K, et al:: Changes in B- and T-lymphocyte and chemokine levels with rituximab treatment in multiple sclerosis. Arch Neurol. 2010; 67(6): 707-714.

PubMed Abstract | Publisher Full Text | Free Full Text

18. Pers JO, Devauchelle V, Daridon C, et al.: BAFF-modulated repopulation of $B$ lymphocytes in the blood and salivary glands of rituximab-treated patients with Sjögren's syndrome. Arthritis Rheum. 2007; 56(5): 1464-1477. PubMed Abstract | Publisher Full Text

19. Vos K, Thurlings RM, Wijbrandts CA, et al.: Early effects of rituximab on the synovial cell infiltrate in patients with rheumatoid arthritis. Arthritis Rheum. 2007; 56(3): 772-778.

PubMed Abstract | Publisher Full Text

20. Kavanaugh A, Rosengren S, Lee SJ, et al.: Assessment of rituximab's immunomodulatory synovial effects (ARISE trial). 1: clinical and synovial biomarker results. Ann Rheum Dis. 2008; 67(3): 402-408. PubMed Abstract | Publisher Full Text | Free Full Text 
21. Marie I, Dominique S, Janvresse A, et al.: Rituximab therapy for refractory interstitial lung disease related to antisynthetase syndrome. Respir Med. 2012; 106(4): 581-587.

PubMed Abstract | Publisher Full Text

22. Henderson SR, Copley SJ, Pusey CD, et al.: Prolonged B cell depletion with rituximab is effective in treating refractory pulmonary granulomatous inflammation in granulomatosis with polyangiitis (GPA). Medicine (Baltimore). 2014; 93(27): e229.

PubMed Abstract | Publisher Full Text | Free Full Text

23. Hadjinicolaou AV, Nisar MK, Parfrey $\mathrm{H}$, et al:: Non-infectious pulmonary toxicity of rituximab: a systematic review. Rheumatol (Oxford). 2012; 51(4): 653-662. PubMed Abstract | Publisher Full Text

24. Bitzan M, Anselmo M, Carpineta L: Rituximab (B-cell depleting antibody) associated lung injury (RALI): a pediatric case and systematic review of the literature. Pediatr Pulmonol. 2009; 44(9): 922-934.

PubMed Abstract | Publisher Full Text

25. Germain C, Gnjatic S, Tamzalit F, et al.: Presence of B cells in tertiary lymphoid structures is associated with a protective immunity in patients with lung cancer. Am J Respir Crit Care Med. 2014; 189(7): 832-844. PubMed Abstract | Publisher Full Text

26. Haabeth OA, Bogen B, Corthay A: A model for cancer-suppressive inflammation Oncoimmunology. 2012; 1(7): 1146-1155.

PubMed Abstract | Publisher Full Text | Free Full Text

27. Corthay A: Does the immune system naturally protect against cancer? Front Immunol. 2014; 5: 197.

PubMed Abstract | Publisher Full Text | Free Full Text 


\section{Open Peer Review}

\section{Current Peer Review Status:}

\section{Version 1}

Reviewer Report 29 March 2016

https://doi.org/10.5256/f1000research.8182.r12922

(c) 2016 Schjerven $\mathbf{H}$ et al. This is an open access peer review report distributed under the terms of the Creative Commons Attribution License, which permits unrestricted use, distribution, and reproduction in any medium, provided the original work is properly cited.

\section{Hilde Schjerven}

Department of Laboratory Medicine, School of Medicine, University of California, San Francisco, San Francisco, CA, USA

\section{Etapong Fonabei Ayongaba}

${ }^{1}$ Department of Laboratory Medicine, School of Medicine, University of California, San Francisco, San Francisco, CA, USA

2 University of Oslo, Oslo, Norway

This well-written paper by Joly-Battaglini et al. describes a case study on the effect of Rituximab on $B$ cells in the lung tissue and tumor microenvironment of a rheumatoid arthritis patient with lung adenocarcinoma. The authors employ the complementing techniques of flow cytometry and immunohistochemistry to show that Rituximab efficiently eliminates CD19+ B cells in the lungs and a majority of CD19+ B cells in the tumor microenvironment, without depleting other lymphoid cells which are not CD20+. Only a low percentage (0.2\%) of CD19+ cells were found in the tumor, and these were suggested to be plasma cells due to lack of HLA-DR by flow cytometry.

This paper confirms the efficiency of Rituximab, and adds new knowledge on its ability to eliminate $B$ cells in lung tissue and tumor microenvironment. The questions asked by the study were approached using appropriate methods, and the paper is clearly written.

Suggestions for minor revisions;

1. It would help the clarity of the paper if the title would indicate that it was a case study. Also, in the title, lung tumor should be corrected to singular, not plural (current title: "lung tumors")

2. It would help the reader if the authors would comment on the life span of B cells with respect to the duration of Rituximab treatment. It would be interesting to see a discussion on whether the low percentage of presumed plasma cells observed in the tumor were from post- or pre- Rituximab treatment. Does Rituximab reach and actively deplete intra-tissue $B$ cells, or is the depletion a result of decreased levels of circulating B cells able to infiltrate 
tissues, and reflects a decrease due to the life-span (or resident time) of tissue-resident B cells?

3. What could the significance of the $0.2 \%$ of plasma cells be with respect to $B$ cell implicated diseases? This could be discussed in light of serum IgG levels and statement of the patient displaying "only moderate clinical effect". It is interesting in regards to the discussion of use of Rituximab for treatment of B-cell mediated diseases (non-cancer) and tissue-resident B cells as opposed to circulating of lymphoid tissue B cells (see point above).

4. What is the statement "The black dots in Figure 5B represent anthracotic pigment in macrophages" based on? Although plausible, a suitable control could for instance be isotype control stain to display this as background, or CD19 (vs e.g. CD11b or similar) stain using a different secondary detection method (that would not detect anthracotic pigment). Although such added experiments might be feasible (if more material is left), it is not required, as it will not affect the main message of the paper in regards to the observed major depletion of $B$ cells.

Overall, the article is well-written, scientifically sound, and presents a case study observation that warrants indexing.

Competing Interests: No competing interests were disclosed.

We confirm that we have read this submission and believe that we have an appropriate level of expertise to confirm that it is of an acceptable scientific standard.

Reviewer Report 03 February 2016

https://doi.org/10.5256/f1000research.8182.r12242

(C) 2016 Huard B. This is an open access peer review report distributed under the terms of the Creative Commons Attribution License, which permits unrestricted use, distribution, and reproduction in any medium, provided the original work is properly cited.

\section{Bertrand Huard}

Department of Oncogenesis and Biotechnology, Joseph Fourier University, Grenoble, France

Title/abstract, content, conclusions, data are all appropriate.

As a minor revision, I would ask authors to speculate on what could be the function of B cells in non infectious lung.

Competing Interests: No competing interests were disclosed.

I confirm that I have read this submission and believe that I have an appropriate level of expertise to confirm that it is of an acceptable scientific standard. 


\section{Comments on this article}

\section{Version 1}

Author Response 25 Feb 2016

Alexandre Corthay, Oslo University Hospital, Oslo, Norway

Thank you very much for your comment and for making us aware of the RRID initiative which we support. RRIDs will be included in the next version of our paper.

Competing Interests: No competing interests were disclosed.

\section{Reader Comment 23 Feb 2016}

Anita Bandrowski, University of California, San Diego, USA

In testing a new tool for methods review, I detected the following research resources in your paper which did not contain the RRID (Research Resource IDentifier). As discussed in the instructions to authors, please consider adding these to the final version of your paper.

RRIDs are universal and persistent product codes and are used for antibodies, software tools and model organisms, see instructions to authors:

http://f1000research.com/for-authors/article-guidelines/research-notes

Please verify the accuracy of the RRIDs below:

Needs attention, not an exact match:

Lab Vision Cat\# RM-9107-R7, RRID:AB_149921

verify: scicrunch.org/resolver/RRID:AB_149921

or search: scicrunch.org/resources/Any/search?q=RM-9107

Exact match based on catalog number detected:

BioLegend Cat\# 307610, RRID:AB_314688 verify: scicrunch.org/resolver/RRID:AB_314688

BioLegend Cat\# 304029, RRID:AB_2174123 verify: scicrunch.org/resolver/RRID:AB_2174123

BioLegend Cat\# 302227, RRID:AB_893276 verify: scicrunch.org/resolver/RRID:AB_893276

BioLegend Cat\# 325617, RRID:AB_830690 verify: scicrunch.org/resolver/RRID:AB_830690

BioLegend Cat\# 344713, RRID:AB_2044005 verify: scicrunch.org/resolver/RRID:AB_2044005

BioLegend Cat\# 317409, RRID:AB_571954 verify: scicrunch.org/resolver/RRID:AB_571954

BioLegend Cat\# 300415, RRID:AB_389310 verify: scicrunch.org/resolver/RRID:AB_389310

Dako Cat\# M0755, RRID:AB_2282030 verify: scicrunch.org/resolver/RRID:AB_2282030

Please consider verifying each antibody highlighted above against the identifier and adding the syntax (vendor catalog RRID) to the final version of the paper.

Competing Interests: No competing interests were disclosed. 
The benefits of publishing with F1000Research:

- Your article is published within days, with no editorial bias

- You can publish traditional articles, null/negative results, case reports, data notes and more

- The peer review process is transparent and collaborative

- Your article is indexed in PubMed after passing peer review

- Dedicated customer support at every stage

For pre-submission enquiries, contact research@f1000.com 